\title{
The learning about imaging diagnosis technology
}

\author{
O aprendizado sobre a tecnologia no diagnóstico por imagem
}

\section{Aparecido Ferreira de Oliveira ${ }^{1}$, Henrique Manoel Lederman ${ }^{2}$, Nildo Alves Batista ${ }^{2}$}

Oliveira AF, Lederman HM, Batista NA. The learning about imaging diagnosis technology. Radiol Bras. 2014 Jan/Fev;47(1):18-22.

Abstract Objective: To investigate the learning about management of the technology (efficient use, acquisition and maintenance of imaging diagnosis equipment) in the radiology residency program of Escola Paulista de Medicina - Universidade Federal de São Paulo, with a view to improving the education of radiologists.

Materials and Methods: Exploratory research where residents, faculty staff and tutors of the program were quantitative and qualitatively approached with Likert scale questionnaires (46), and deepening with recorded interviews (18) and categorization based upon meaning units (thematic analysis).

Results: Among the participants, $66 \%$ agreed that they had the opportunity of learning about the use of radiological equipment; for $61 \%$ the program should include knowledge on the importance of acquiring equipment; and $72 \%$ emphasized the lack of learning about equipment management and maintenance.

Conclusion: As the major moment in the education of specialists, the medical residency program provides residents with a favorable environment to the learning of the skills required to the future of their professional practice, but with limited emphasis on the management of the technology: efficient use, acquisition and mainly maintenance of equipment, still poorly explored. Both the investigated program and the medical residency in radiology should incorporate, whenever possible, the commitment with the training in supplementary skills related to equipment management, developing the competence of the future radiologists.

Keywords: Medical education; Medical residency; Health management; Radiologic technology; Radiology; Imaging diagnosis.

Resu mo Objetivo: Investigar a aprendizagem sobre gestão da tecnologia (uso eficiente, compras e manutenção de equipamentos de diagnóstico por imagem) na residência em radiologia da Escola Paulista de Medicina - Universidade Federal de São Paulo, procurando o aprimoramento da formação do radiologista.

Materiais e Métodos: Pesquisa exploratória, com abordagem quantitativa e qualitativa junto a residentes, docentes e preceptores do programa, utilizando-se questionários no formato Likert (46) e aprofundamento com entrevistas gravadas (18) e categorização a partir das unidades de significado (análise temática).

Resultados: Dos participantes do estudo, $66 \%$ concordam haver a oportunidade de aprendizado sobre a utilização dos equipamentos radiológicos, para $61 \%$ o programa deveria contemplar o aprendizado da importância da compra dos equipamentos e $72 \%$ são enfáticos em afirmar a inexistência do aprendizado sobre o gerenciamento da manutenção dos equipamentos.

Conclusão: 0 programa de residência médica, como principal momento formativo na especialidade, fornece ao residente um ambiente propício ao aprendizado das habilidades necessárias ao futuro exercício profissional, mas com ênfase restrita à gestão da tecnologia: uso eficiente, compras e principalmente manutenção de equipamentos, ainda pouco explorados. Assim como o programa investigado, a residência médica em radiologia poderia incorporar, dentro do possível, o compromisso com o treinamento de habilidades complementares de gestão de equipamentos, ampliando a competência dos futuros radiologistas.

Unitermos: Educação médica; Residência médica; Gestão em saúde; Tecnologia radiológica; Radiologia; Diagnóstico por imagem.

\section{INTRODUCTION}

Radiology is a specialty of diagnostic and therapeutic support, whose procedures demand integrated and complementary multidisciplinary activity, incorporating complex

* Study developed at Escola Paulista de Medicina - Universidade Federal de São Paulo (EPM-Unifesp), São Paulo, SP, Brazil.

1. Master, Professor of Health Sciences, Fellow PhD degree, Escola Paulista de Medicina - Universidade Federal de São Paulo (EPM-Unifesp), São Paulo, SP, Brazil.

2. Teachers, Full Professors, Escola Paulista de Medicina - Universidade Federal de São Paulo (EPM-Unifesp), São Paulo, SP, Brazil.

Mailing Address: Aparecido Ferreira de Oliveira. Centro de Desenvolvimento do Ensino Superior em Saúde - Universidade Federal de São Paulo (Cedess-Unifesp). Rua Pedro de Toledo, 859, Vila Clementino. São Paulo, SP, Brazil, 04039-032. E-mail: aparecidoliveira@ig.com.br.

Received January 23, 2013. Accepted after revision September 10, 2013. processes and cutting-edge technology, with high investments in equipment, techniques, resources and materials; and it is up to the professionals combining technical/scientific knowledge with administrative skills for an effective performance of their role.

In practice, radiologists operate modern and sophisticated equipment, utilizing computer programs. The information technology has brought the digital era, interconnecting equipment with images and reports stored as files in computers and distributed unlimitedly in terms of time and geographic location. Digital radiology has revolutionized the daily routine of the radiological practice, imposing challenges of initial investment costs reduction by increasing the productivity and improving the images quality. 
According to Azevedo-Marques et al. ${ }^{(1)}$, digital radiological information can be consistently, reliably and automatically transmitted both inside and outside the hospital environment, provided information safety protocols are respected.

Caritá et al. ${ }^{(2)}$ emphasize that "Picture Archiving and Communication Systems - PACS) have already become the preferred technological option for tasks of transmission, storage and visualization of data in the field of imaging diagnosis." The authors also assert that such system allows for content-based image retrieval - CBIR, a system that was created to extract the characteristics of images stored in the PACS, indexing them for later retrieval by similarity (PACSCBIR).

Silva et al. ${ }^{(3)}$ add that "PACS requires images format standardization besides two additional administrative systems, namely, Radiology Information System - RIS) and Hospital Information System - HIS) to support patients' data recording, reporting, imaging findings documentation, among others."

The DICOM (digital imaging and communications in medicine) standard was adopted for communication and storage of medical images and associated data, and is widely utilized, differing from the other imaging formats such as JPEG, TIFF, GIF, among others, since it allows for storage of patients' data with the images in a structured way, in spite of being based on the JPEG format, either compressed or not.

Other technologies have been associated with the DICOM standard, allowing a better interconnection between the systems, such as the implementation of the worklist. Another system integration standard is the HL7 (health level 7) that is aimed at simplifying the implementation of interfaces between the different computer applications developed by the competition ${ }^{(4)}$.

Santos et al. ${ }^{(5)}$ add that PACS may also be utilized as a didactic resource (either in the e-learning or distance learning modalities), allowing for the students interaction with images along their learning process.

Chan ${ }^{(6)}$ emphasizes that programs of residency in radiology should allow the practice of the leadership managerial skills, teamwork, discussions, analyses and decision making about technical issues affecting the radiological practice.

The medical residency is a specialized learning modality provided by health institutions accredited by the Comissão Nacional de Residência Médica (CNRM) (National Commission of Medical Residency), created by Decree No. $80.281 / 77^{(7)}$, under the guidance of medical professionals with high ethical and professional qualification, assigning, at the end of the program, a title of specialist, according to the Law 6.932/81 ${ }^{(8)}$. The minimum requirements for the accreditation of programs of residency in radiology were defined by the CNRM Resolution $4 / 83^{(9)}$.

Boechat et al. ${ }^{(10)}$ comment that "In Brazil, the Comissão Nacional de Residência Médica (CNRM) has created Standards and criteria for accreditation of program of residency in radiology, and Colégio Brasileiro de Radiologia (CBR)
(Brazilian College of Radiology) has established minimum requirements to allow such services to offer training in such a specialty." Still, about residency in radiology, these authors assert that "at the end of the training, the resident physicians must be qualified to critically utilize all the resources which will allow the continuation of their skills improvement throughout their professional life."

According to Silva et al. ${ }^{(11)}$, the "Technological and scientific developments in the field of radiology and imaging diagnosis allow for professional qualification based on the acquisition of new competencies and abilities during the medical residency and specialization courses according to the capabilities and expectations of the professionals, provided opportunities are offered to them."

Thus, residency programs must prepare the future professional to know the technology involved in the daily routine of the specialty, thus enhancing the radiologist competence. Therefore, the addition of supplementary abilities such as those related to the process of selection, choice, acquisition and maintenance of equipment, considering their diagnostic applications, involved costs, technological updating and replacement contribute in the decision making, planning and organization of radiology services. All these factors imply in a multidisciplinary character of the working force, involving not only radiologists but also professionals in the area of direct support (nursing, technologists, technicians and administration team) and those support areas such as biomedical engineering and information technology adding efforts and practices focused on shared institutional objectives.

In this scenario, some questions arise: How is the program of residency in radiology at Escola Paulista de Medicina - Universidade Federal de São Paulo (EPMUnifesp) preparing residents to deal with technological resources required in the radiological practice? Which are the strengths and limitations for such learning?

The present study was aimed at investigating the learning about the management of technological resources among residents, teachers and preceptors in the program of residency in radiology at EPM-Unifesp, seeking inputs to improve the education of radiologists.

\section{MATERIALS AND METHODS}

The analyzed Program of Medical Residency in Programa de Residência Médica in Radiology has a duration of three years, for 12 participants at the first years (R1), 12 at the second (R2) and 12 at the third year (R3), relying on one supervisor teacher, one teaching \& research coordinator, two head preceptors and 11 discipline preceptors distributed as follows: abdomen; head \& neck; musculoskeletal system; breast; pediatrics; chest; fetal medicine; emergency; intervention and neurology. Additionally, the whole department staff comprising teachers, collaborating physicians, administrative education technicians and participants in the professional updating program participate in the residents education. 
The authors have opted for an exploratory study with qualitative and quantitative approaches developed in 2011, involving the universe of residents, preceptors and teachers included in the Program, after approval by the Committee for Ethics in Research of Unifesp.

In the first phase of the study, 46 research subjects (75.40\%), among the 61 individuals included in the analyzed universe, responded to a Likert attitudinal scale including 11 assertions, three of them regarding to the present article thematics.

Amaro et al. ${ }^{(12)}$ comment that the Likert scale presents a series of five propositions, one of which should be selected by the respondent: totally agree; agree; no opinion, disagree, totally disagree in relation to the assertions related to the study subject. The data obtained were tabulated and organized as charts.

As a strategy to deepen the data collection process, a second phase was undertaken with a seven-question interview (mean duration of 10 minutes) and a number of respondents according to qualitative criteria, i.e., information relevance and reincidence and data saturation, which has occurred after the 18th interview.

After complete data transcription, the data set was submitted to a thematic analysis (nuclei of meaning) that is one of the contents analysis techniques, as proposed by Minayo ${ }^{(13)}$ : arrangement of data after reading the obtained material, identification and establishment of context units (where the message is included), identification of the recording units (word, phrase or sentence) regarding the analyzed object and grouping of such units into analysis categories.

\section{RESULTS}

Five out the nine available teachers participated in the study (55.5\% of the category). All of them were men, aged between 44 and 59 years, with mean teaching experience time of 20 years.

The 14 preceptors $-10(71 \%)$ men and $4(29 \%)$ women - were, on average, 51 years old; $86 \%$ of them came from public schools and $14 \%$ from private schools. Seven preceptors informed their preceptorship time with a mean variation of 19.5 years.

Amongst the 27 residents ( $70 \%$ men and $30 \%$ women), $10 \mathrm{R} 1,7 \mathrm{R} 2$, and $10 \mathrm{R} 3$ participated in the study.

With a mean age of 27 years, $60 \%$ of the ten $\mathrm{R} 1$ were men and $40 \%$ were women; $70 \%$ graduated in public schools and $30 \%$ in private schools, for six to ten months. Amongst the seven R2, the mean age was 28 years, $86 \%$ were men and $14 \%$ were women. Six came from public schools and one, from private school, and graduated for one and a half to Five and a half years. On the other hand, amongst the $10 \mathrm{R} 3$, the mean age was 29 years; $70 \%$ were men and $30 \%$, women; $90 \%$ had graduated in public schools and $10 \%$ in private schools, for two and a half to seven and a half years.

More than half $(66 \%)$ of the teachers, preceptors and residents in the investigated program agreed that there was opportunity to learn how to effectively use radiological equipment (Figure 1): "you learn how to handle the equipment efficiently and when to handle each equipment." E11 and "He can and has the opportunity to learn how to handle the radiological equipment and bring out its best." E13. However, 32\% of them disagree: "I think it is a fallacy, a misunderstanding that most interviewers believe they have opportunity to learn how to use equipment with efficiency." E17; "there is no way to learn how to use equipment efficiently." E16.

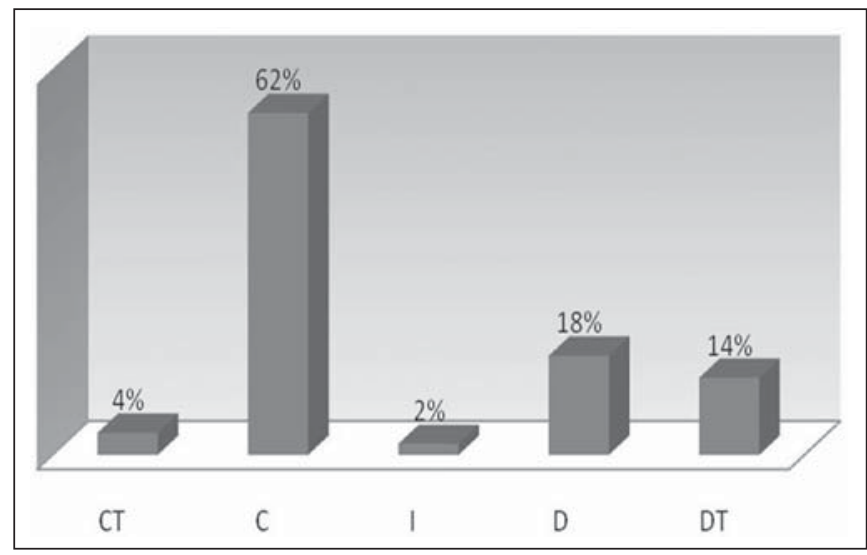

Figure 1. Rate of agreement/disagreement on the opportunity of learning about the efficient use of radiological equipment.

For $61 \%$ of the teachers, preceptors and residents, the program should include the learning about the relevance of the radiological equipment acquisition process (Figure 2): "this issue is neither mentioned nor sufficiently developed during the residency; this is one thing missing." E02; and "the relevance of the (equipment) acquisition process is more or less implied in the imaging diagnosis profession but, during residency, he does not have that notion." E16. Also, it is important to mention that $39 \%$ disagree from the majority: "the residency program is not focused on business, but on the academy, where the study of the patients is more important than equipment acquisition." E15.

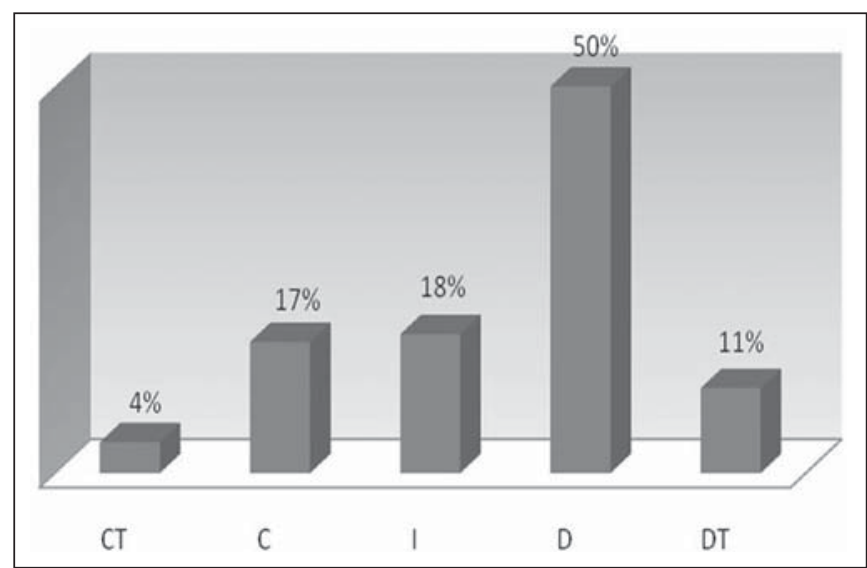

Figure 2. Rate of agreement/disagreement on the opportunity of learning about acquisition of radiological equipment. 
Even more emphatic about the learning on the management of radiological equipment maintenance (Figure 3), $72 \%$ of the respondents say that there is no opportunity to develop such ability during residency: "Maintenance? No, we do not learn how to manage the equipment maintenance." E06 and "there is not a minimal opportunity, at least in my sector, to learn how to manage and how to make equipment maintenance." E16.

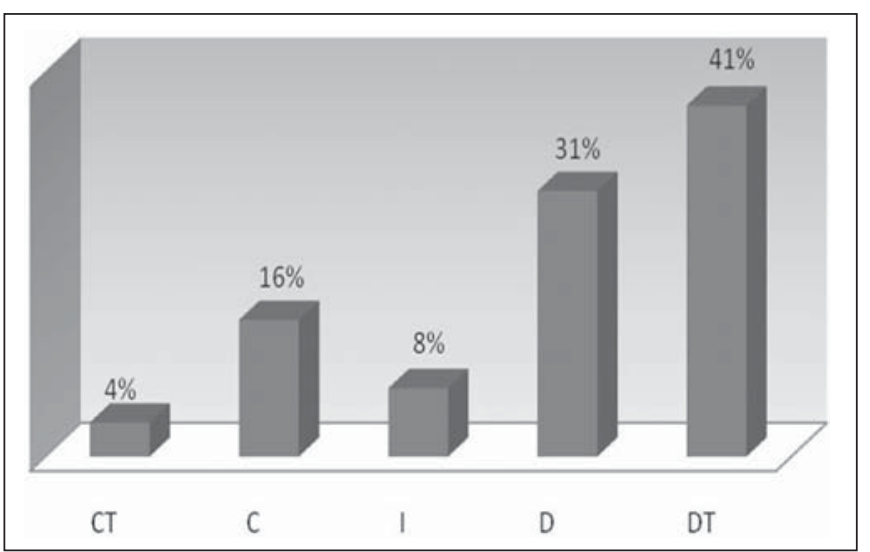

Figure 3. Rate of agreement/disagreement on the opportunity of learning about management of radiological equipment maintenance.

The in-depth interviews allowed the appraisal of opportunities and limitations for the learning of such abilities, with predominance of limitations. Program structuring and education time were mentioned as opportunities.

However, the limitations prevailed with lack of emphasis on the program, infrastructure specificity (lack of appropriate environment), as well as lack of interest of the residents themselves in deepening their knowledge: "the resident who individually is interested in the theme may even find some answers." E14.

One of the respondents comments that "the education is traditional and does not involve this type of reflection." E01, reinforcing the necessity of the program to include the learning of new competencies.

\section{DISCUSSION}

In the topic management of technological resources, the learning of the future radiologist about the effective utilization of sophisticated and highly expensive radiological equipment shows to be relevant, since the intensive daily use of such equipment affects the procedures routine, from their performance to the images interpretation, due to the gains in images quality and reports accuracy. According to the residents, preceptors and teachers, the possibilities of learning with a view on the effective use of radiological equipment show to be controversial. Despite the agreement of $66 \%$ of the population, $32 \%$ have emphatically disagreed about the occurrence of such learning.

According to Briani ${ }^{(14)}$, "the influence from the labor market and from the adoption of increasingly advanced tech- nological resources in the clinical practice brings undeniable effects on the education", whose programs must be updated, renewed and modernized.

In order to make a better use of equipment, it is necessary to learn about their acquisition and maintenance. In spite of usually being a technical task, involving clinical engineering, information technology and data provided by manufacturers, the greater the radiologist's knowledge about types, models and applications, contracts, acquisition prices, repairs and warranties, the higher the efficiency of their practice. Such aspects are not contemplated in the program in the view of the respondents.

Castilho ${ }^{(15)}$ emphasizes the necessity of professional education in such aspects, considering "..the increasing development and replacement of technologies which continuously challenge both layman and professional users' abilities as regards their effective understanding, appropriation and management."

The efficacious interaction and use of radiological equipment, particularly regarding imaging quality, as an aid in the images interpretation and reporting, substantially rely on technological developments.

Santos ${ }^{(16)}$, as regards the use of new technologies in the radiological practice, says: "also, it calls attention to the necessity of personnel training and to individual difficulties in the use of new technologies. Such difficulties tend to decrease to a minimum with the routine use of digital reporting and continuous training on this technology."

It is important to highlight the relevance of teaching about such topics in residency - a moment of practical application of the specialty theoretical knowledge. Despite the innumerable advances, many residency programs lack room for discussion with a view on the introduction of the learning of new abilities and competencies, particularly about management, required for the professional practice.

Lopes et al. ${ }^{(17)}$ assert that "despite the advances in educational policies, the health institutions have reproduced such more traditional education practices.", still distant from a wider, contemporary education focused on the reality of the professional market.

\section{CONCLUSIONS}

The present study has demonstrated that:

1 . There is a controversy concerning the opportunity to residents to learn about how to effectively utilize radiological equipment.

2. More than half of the respondents disagree as regards the possibility of learning about the acquisition of imaging diagnosis equipment during medical residency.

3. The opportunity to learn and manage the equipment maintenance is denied by $72 \%$ of the respondents.

4. The lack of infrastructure and emphasis on the program, the time from graduation, and the lack of interest of the resident were the main factors indicated as limitations to a better learning about the efficient use, acquisition and maintenance of imaging diagnosis equipment. 
The authors consider that radiology is a medical specialty involving diagnostic and therapeutic support of interdisciplinary character with procedures performed by a multiprofessional team by means of complex processes employing cutting-edge technology, hence the radiologists' leadership role also in the organization, planning and management of the flows of the service.

The medical residency program represents a major educational moment where the future specialists have their role defined and their autonomy developed to perform their practice. Therefore, the program must contemplate the development of competencies related to the management of technology, enabling the resident to learn about the efficient use, acquisition and mainly maintenance of equipment, still poorly explored at this stage of their education.

Both the investigated program and the medical residency in radiology should undergo a revision, initially with a cycle of lectures, case reports and debates about relevant aspects of technology and its impact on the daily routine of radiology, with later inclusion of elective disciplines, incorporating, whenever possible, the commitment with the training in supplementary skills related to equipment management, developing the competence of the future radiologists.

\section{REFERENCES}

1. Azevedo-Marques PM, Salomão SC. PACS: sistemas de arquivamento e distribuição de imagens. Rev Bras Fís Méd. 2009;3:131-9.

2. Caritá EC, Seraphim E, Honda MO, et al. Implementação e avaliação de um sistema de gerenciamento de imagens médicas com suporte à recuperação baseada em conteúdo. Radiol Bras. 2008;41: $331-6$.

3. Silva CPG, Gambarato VTS. Descrição da implantação do PACS (Picture Archiving and Communication System) em um hospitalescola para redução de custos operacionais. Tékhne \& Lógos. 2012;3:1-20.

4. Caritá EC, Matos ALM, Azevedo-Marques PM. Ferramentas para visualização de imagens médicas em um hospital universitário. Radiol Bras. 2004;37:437-40.

5. Santos AN, Mercado LPL. Arquivamento e comunicação de imagens na formação médica online. Rev Bras Educ Méd. 2010;34:52534.

6. Chan S. Management education during radiology residency: development of an educational practice. Acad Radiol. 2004;11:130817.

7. Brasil. Ministério da Educação. Decreto ${ }^{\circ} 80.281$ de 05 de setembro de 1977. Regulamenta a Residência Médica, cria a Comissão Nacional de Residência Médica e dá outras providências. [acessado em 12 de novembro de 2012]. Disponível em: http://www.ccm.ufpb. br/arquivosdosite/posgraduacao/Decreto\%2080.281.pdf.

8. Brasil. Ministério da Educação. Lei nº ${ }^{\circ} 6.932$ de 07 de julho de 1981. Dispõe sobre as atividades do médico residente e dá outras providências. [acessado em 12 de fevereiro de 2012]. Disponível em: http:/ /portal.mec.gov.br/index.php?option=com_content \&view=article\& id $=13086 \&$ Itemid $=506$.

9. Sousa EG, Koch HA. A residência em radiologia: o ponto de vista do médico residente. Radiol Bras. 2001;34:65-70.

10. Boéchat AL, Sousa EG, Moreira FA, et al. Proposta de um programa básico para a formação do médico residente em radiologia e diagnóstico por imagem. Radiol Bras. 2007;40:33-7.

11. Silva GCC, Koch HA, Souza EG. O perfil do médico em formação em radiologia e diagnóstico por imagem. Radiol Bras. 2007;40:99_ 103.

12. Amaro A, Póvoa A, Macedo LA. A arte de fazer questionários. [Tese de mestrado]. Porto, Portugal; Faculdade de Ciência da Universidade do Porto; 2005.

13. Minayo MCS. O desafio do conhecimento. Pesquisa qualitativa em saúde. $6^{a}$ ed. São Paulo: Hucitec; 1999.

14. Briani MC. O ensino médico no Brasil está mudando? Rev Bras Educ Méd. 2001;25:73-7.

15. Castilho APRN. Gestão da informação e de novas tecnologias. RAF - Revista Acadêmica FIT. 2005;1:10-4.

16. Santos AASMD. Radiologia digital: como fica o laudo radiológico? Radiol Bras. 2010;43:ix-x.

17. Lopes EFS, Perdomini FRI, Flores GE, et al. Educação em saúde: um desafio para a transformação da práxis no cuidado em enfermagem. Rev HCPA. 2007;27:25-7. 